\title{
Composition and origin of sediments on the mid-oceanic Kolbeinsey Ridge, north of Iceland
}

\author{
K.S. Lackschewitz and H.-J. Wallrabe-Adams \\ GEOMAR, Research Centre for Marine Geosciences, Wischhofstrasse 1-3, D-2300 Kiel 14, FRG
}

(Received December 10, 1989; revision accepted August 1, 1990)

\begin{abstract}
Lackschewitz, K.S. and Wallrabe-Adams, H.-J., 1991. Composition and origin of sediments on the mid-oceanic Kolbeinsey Ridge, north of Iceland. In: T.O. Vorren, H. Sejrup and J. Thiede (Editors), Cenozoic Geology of the Northwest European Continental Margin and Adjacent Deep Sea Areas. Mar. Geol., 101: 71-82.

In order to characterize the sediments of the South Kolbeinsey Ridge and to determine the influence of morpho- and hydrodynamic conditions in this area, a comprehensive sedimentological investigation was combined with detailed geochemical analyses.

Lithological composition and grain size are mainly controlled by the input from two different sources: the submarine, active mid-ocean ridge and Iceland. Coarse-grained volcanic material dominates in the ridge area, whereas fine-grained detritus from Iceland characterizes the adjacent basin. Further, the distribution of these sediments is largely influenced by hydrodynamic conditions and redeposition processes. Strong bottom-water currents indicated by the benthic foraminifer species Cibicides lobatulus prevent extensive deposition of fine-grained material on the top of the ridge. The ridge slope is characterized by redeposited sediments of various grain sizes.

Bulk-sediment chemical analyses show element distribution patterns that are strongly correlated with the ratio of volcanic vs. detritic particle composition. This ratio reflects particle input and distribution processes. Two element associations are notable: elements coupled with (1) ridge-derived volcanic particles and (2) the detrital $<2 \mu \mathrm{m}$ fraction which reflects weathered material from Iceland.
\end{abstract}

\section{Introduction}

Kolbeinsey Ridge is the section of the MidAtlantic Ridge north of Iceland beginning at about $66^{\circ} \mathrm{N}$ and extending in a northward direction to the Jan Mayen Fracture Zone near $71^{\circ} \mathrm{N}$. This area is the target of a research programme, which started in 1987 , to investigate sediment distribution and composition along an active mid-ocean ridge segment. In 1988 surface sediment samples and boxcores from southern Kolbeinsey Ridge $\left(67^{\circ} 10^{\circ} \mathrm{N}, 18^{\circ} 50^{\circ} \mathrm{W}\right.$; water depth $\left.100-460 \mathrm{~m}\right)$ were studied.

South of the Island of Kolbeinsey (ca. 60 nautical miles $(\mathrm{nm})$ north of Iceland) the ridge is characterized by a rough morphology. Seismic profiles record a rift valley which grades northwards into a sharp ridge crest and a smooth ridge north of the Spar Fracture Zone. The spreading velocity approximates $2 \mathrm{~cm} / \mathrm{yr}$ (Vogt, 1983).

Sediment investigations from a mid-ocean ridge segment comparable to the area described in this paper have already been published by Horowitz (1974), who described sedimentological, mineralogical and geochemical results from the Reykjanes Ridge and the southwestern coast of Iceland.

In general, the Kolbeinsey Ridge in the study area is almost devoid of sediments. The sediment thickness increases towards the flanks and the adjacent plain. Figure 1 shows the present morphology of the investigated area derived from a $3.5 \mathrm{kHz}$ echoprofile. This profile is situated approximatly $3 \mathrm{~nm}$ south of Kolbeinsey Island, crossing the crest and western slope of the ridge in a $\mathrm{SE}-\mathrm{NW}$ direction.

The main surface current systems of the Ice- 

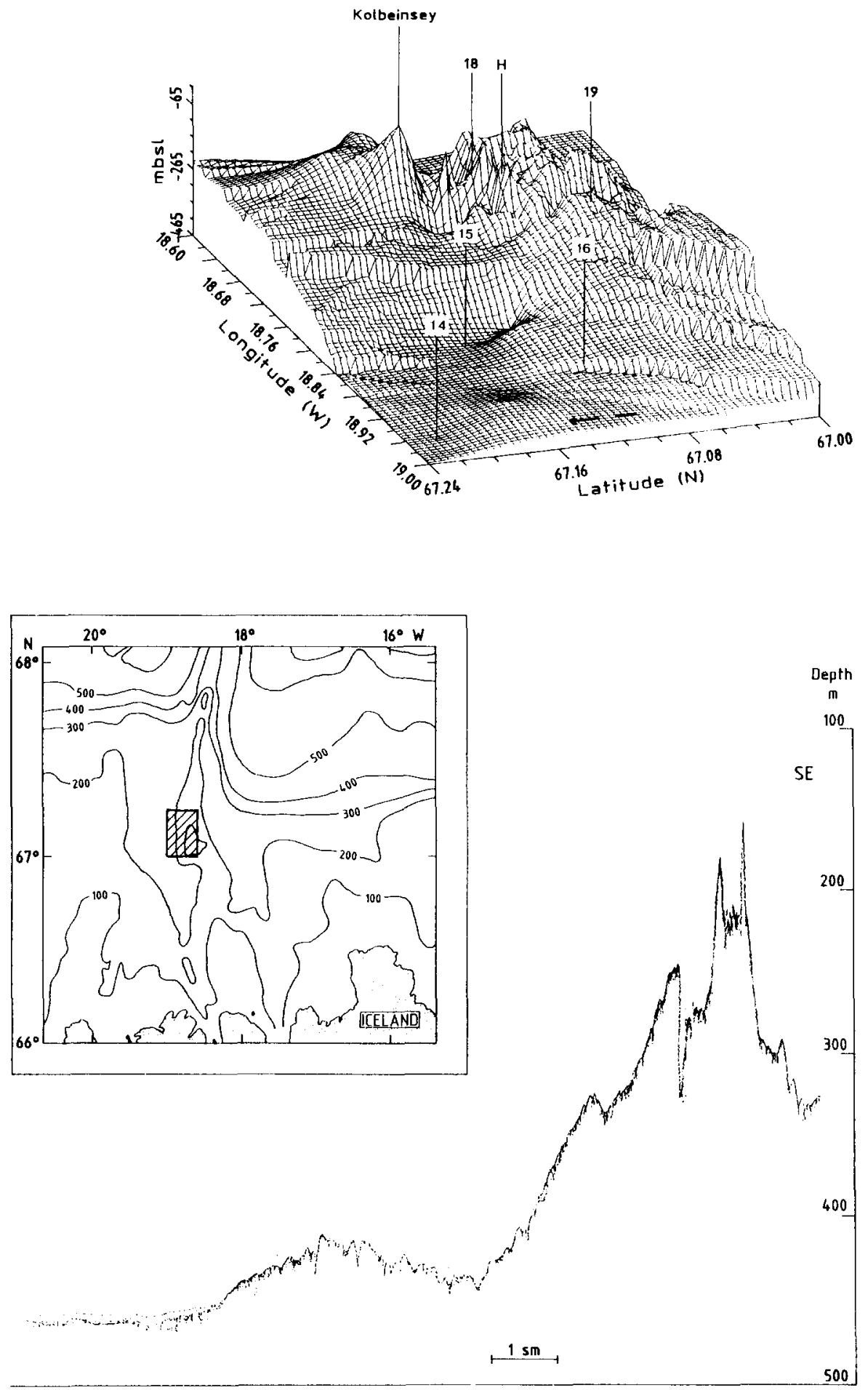

Fig. 1. Location of the study area and main morphological features. Locations of sites 014 to 019 are shown in the $3 \mathrm{D}$ diagram and in the $3.5 \mathrm{kHz}$ profile. Note that positions on the $3.5 \mathrm{kHz}$ profile are only relative to morphology - they are not true locations 
landic Sea influencing the study area are the East Greenland Current, the East Icelandic Current, and the Norwegian Atlantic Current (Fig. 2) (Stefansson, 1962).

The volcaniclastic material in the marine sequences, and predominantly in the Kolbeinsey Ridge area, has been derived from many types of depositional processes. Some are the result of eruptions on land and ash fallout into water, and some involve transport from land to the sea after erosion. Still other processes involved underwater eruptions, which extrude volcanic fragments of various types. The transport of submarine volcaniclastic material into the adjacent basins can occur by a variety of remobilization processes.

It is the purpose of this study to present the geochemistry of the bulk sediment and sedimentological properties in order to clarify the sources, processes of distribution and deposition and chemical changes pertaining to the mid-ocean ridge sediments and to the sediments of the adjacent basin.

\section{Sampling}

Sediment was collected by box coring during R.V. "Polarstern" cruise ARK V/lb in 1988 (sites

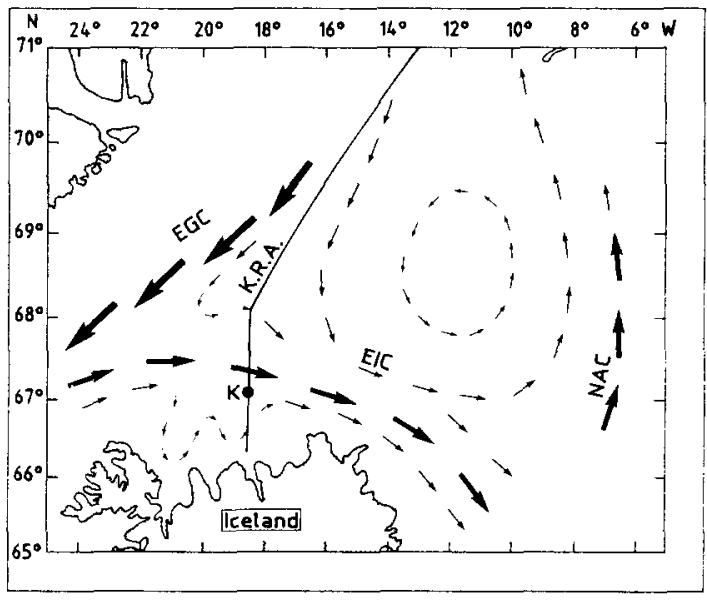

$$
\begin{aligned}
& \text { EGC = East Greenland Current } \\
& \text { EIC = East Icelandic Current } \\
& \text { NAC }=\text { Norwegian Atlantic Current } \\
& \text { K.R.A. }=\text { Kolbeinsey Ridge Axis } \\
& \text { K }=\text { Kolbeinsey Island }
\end{aligned}
$$

Fig. 2. Recent surface-water current system north of Iceland (from Stefansson, 1962).
13/014-13/019). Sediment samples were selected from five boxcores at intervals of $2-3 \mathrm{~cm}$.

The following investigations were performed: $\mathrm{X}$-ray radiography, bulk carbonate and organic carbon measurements, coarse-grain analysis (from a sample split into $125-500 \mu \mathrm{m}$ and $>500 \mu \mathrm{m}$ fractions), X-ray diffraction analysis, and micropaleontological studies $(63-500 \mu \mathrm{m}$ fraction).

For the chemical element distribution study, samples were centrifuged with distilled water to remove salts. The major and trace element content of the sediments was analyzed by X-ray fluoresence spectroscopy (Siemens SRS 300, with melting tablets of $600 \mathrm{mg}$ sample $+3600 \mathrm{mg} \mathrm{Li}{ }_{2} \mathrm{~B}_{4} \mathrm{O}_{7}$ and pressure tablets from N.U. Tech GmbH, Neumünster, FRG). The element distribution in the volcanic glass particles was measured by electron microprobe analysis. ${ }^{14} \mathrm{C}$ measurements on shell valves were carried out by the ${ }^{14} \mathrm{C}$ Laboratory of the Institute of Nuclear Physics at Kiel University.

Dissolution studies on foraminifer tests were carried out with the SEM at the Geological Institute at Kiel University.

\section{Results}

As inferred from the freshness of the basalt samples and the presence of hydrothermal activity, the area around Kolbeinsey Island is a young, active ridge segment (Spindler, 1989). The sediment cover on the ridge crest is restricted to small sediment pockets (a few tens to a few hundred metres in size). Thick sediment sequences occur in the adjacent basins (Fig. 1, $3.5 \mathrm{kHz}$ profile).

Valves of Mya truncata, Saxicava arctica, Pecten islandica and Macoma calcarea from sample 019 at a core depth of $15 \mathrm{~cm}$ exhibit an age of $10,140 \pm 20$ yrs B.P. $\left({ }^{14} \mathrm{C}\right.$ dating $)$.

\section{Lithology}

In general the sediment colour ranges from dark yellowish brown (boxcore 014) to olive grey and black (boxcores 016 to 019 ).

All samples from the ridge crest and slope (015 to 019) are dominated by fine to coarse sand which has an olive grey to dark grey and black colour (Fig. 3). From the top to a core depth of approxi- 
mately $3-4 \mathrm{~cm}$ the sediment is oxidized and has a dark yellowish brown colour. Cores from the slope (015 and 016) consist of several layers and lenses of sandy silty clay, medium to coarse sand, and fine gravel. The layers often show scoured, gradational contacts caused by bioturbation. The sediment from the adjacent plain (014) consists of predominantly silty clay with a few intercalated

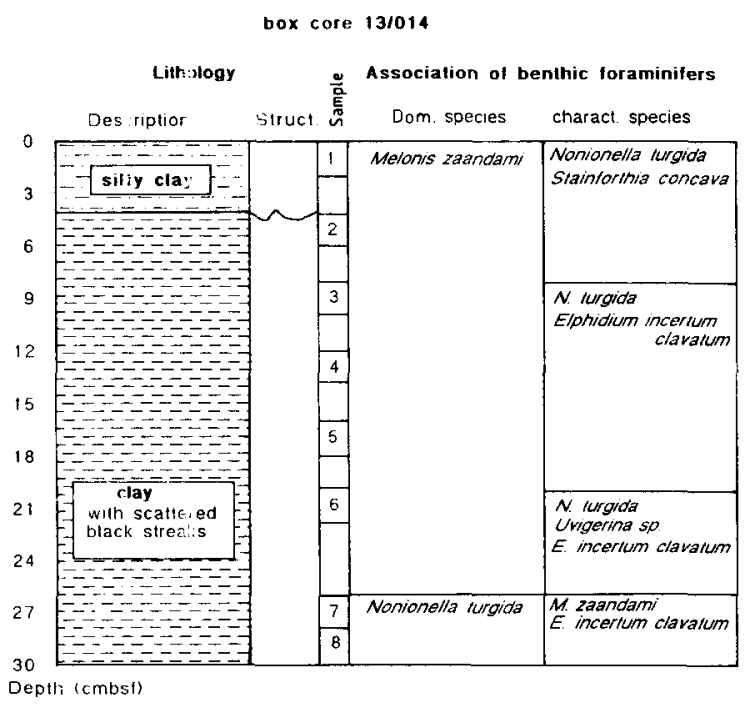

box core 13/016

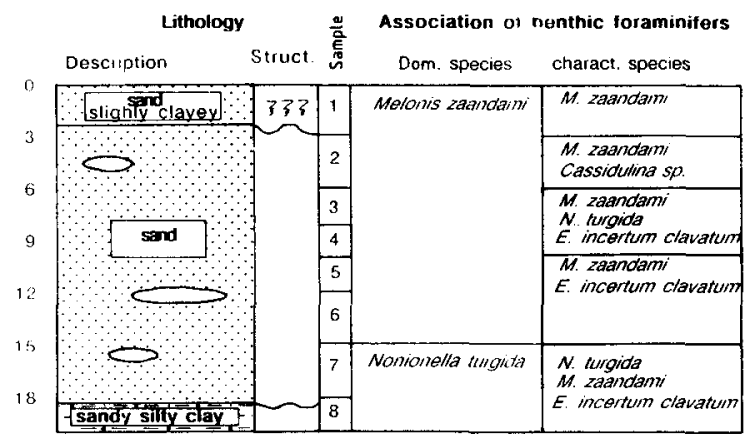

Depth (cmbst)
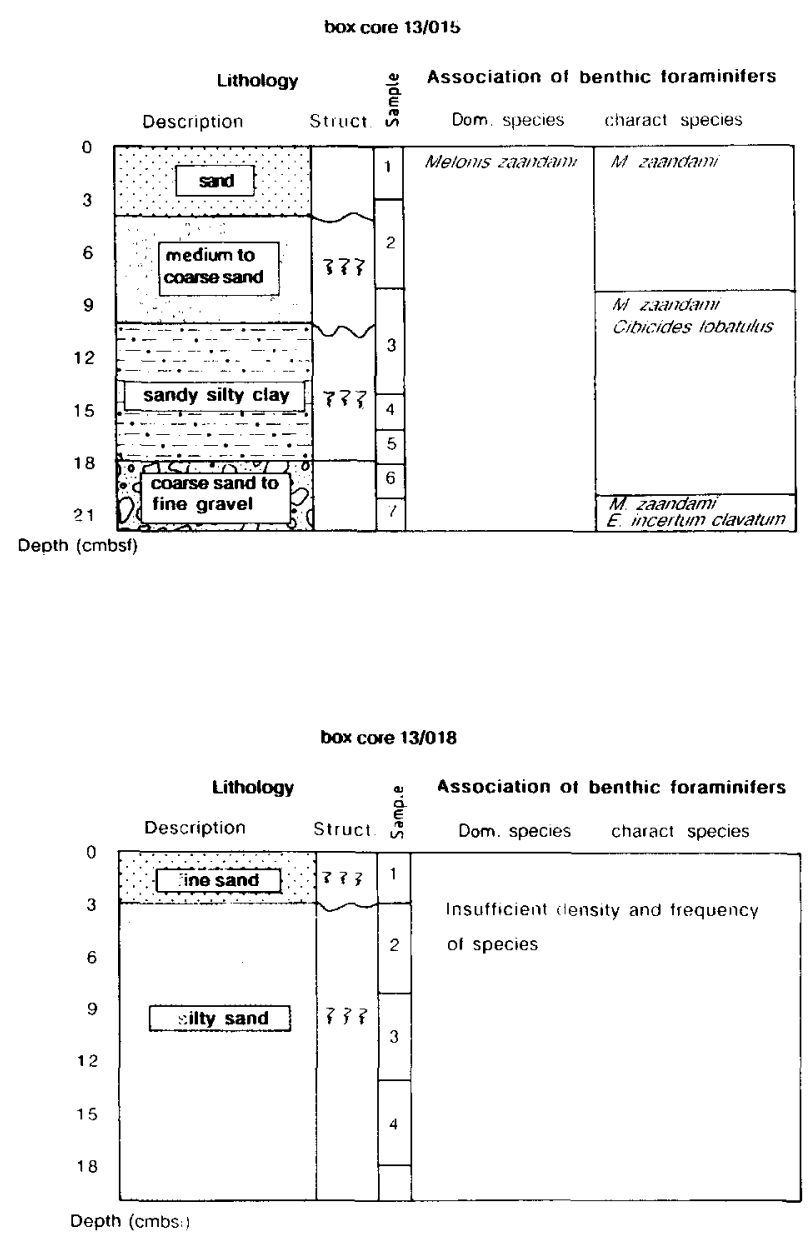

Legend

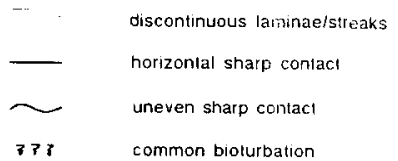

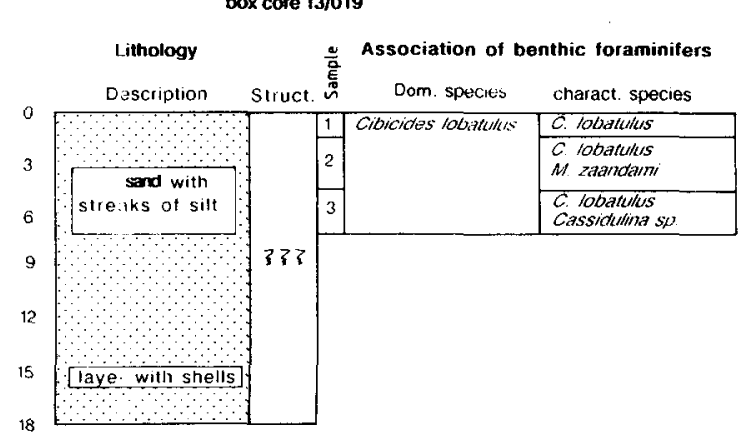

Depth (cmbsi.

Fig. 3. Lithology and benthic foraminifer assemblages at sites 014 to 019 . 
lenses of coarser volcanic material. The whole core is dark yellowish brown.

All sediments are unconsolidated. In boxcore 016, Fe-rich concretions occur.

\section{Coarse-grained sediment components}

The coarse fraction is composed of volcanic, biogenic and lithogenic components (Table 1). The most important constituent is volcanic glass, which can be divided into several morphological types. The volcanic glass content reaches nearly $88 \%$ on the ridge crest, and most of volcanic glass particles show a highly vesicular, pumice-like texture. The overall grain shape is controlled by vesicle shape. Generally, both concentration and grain size of volcanic glass increase towards the ridge crest.

Minor amounts of biogenic calcareous and biogenic silicaceous particles, dominated by sponge spicules $(0.5-18 \%)$, are found in the sediment. In all samples the biogenic calcareous components are dominated by benthic foraminifers, whereas planktonic foraminifers are scarce. Component analyses reveal two characteristic types of benthic test assemblages (Fig. 3). A first assemblage is dominated by Melonis zaandami (Van Voorthuysen) associated with minor amounts of Nonionella turgida (Williamson), Elphidium incertum clavatum (Terquem), Stainforthia concava (Höglund), Uvigerina spp. and Cassidulina spp. The highest amounts of $M$. zaandami occur in the surface samples of sites $014(41 \%), 015(46 \%)$ and 016 $(31 \%)$ with $<20 \% N$. turgida, $<15 \%$ E. incertum

\section{TABLE 1}

Component composition of the coarse fraction $(125-500 \mu \mathrm{m})$ and grain-size distribution of the analyzed surface sediments. Note the high content of the fine fraction $(<2 \mu \mathrm{m})$ at site 014

\begin{tabular}{lrrrrr}
\hline $\begin{array}{l}\text { Component* } \\
(\%)\end{array}$ & $\begin{array}{r}\text { Site } \\
014\end{array}$ & $\begin{array}{r}\text { Site } \\
015\end{array}$ & $\begin{array}{r}\text { Site } \\
016\end{array}$ & $\begin{array}{r}\text { Site } \\
018\end{array}$ & $\begin{array}{r}\text { Site } \\
019\end{array}$ \\
\hline $\begin{array}{l}\text { Terrigenous } \\
\text { Biogenic }\end{array}$ & 10.2 & 8.7 & 11.8 & 10.8 & 11.7 \\
Volcanic & 17.4 & 6.4 & 0.6 & 2.9 & 2.2 \\
$\begin{array}{l}\text { Grain size (wt\%) } \\
<2 \mu \mathrm{m}\end{array}$ & 72.4 & 84.9 & 87.6 & 86.3 & 86.1 \\
$2-63 \mu \mathrm{m}$ & 10.0 & 6.8 & 18.0 & 0.7 & 4.7 \\
$63-500 \mu \mathrm{m}$ & 3.0 & 43.6 & 46.1 & 87.7 & 90.7 \\
$>500 \mu \mathrm{m}$ & 0.2 & 42.4 & 13.1 & 10.7 & 1.2 \\
\hline
\end{tabular}

clavatum and $<5 \%$ of the other benthic species. Mackensen (1987) and Wagener (1988) suggested that the dissemination of Melonis zaandami is associated with fine sediment with a high organic carbon content. The $\mathrm{C}_{\text {org }}$ content in sites 014 to 019 ranges from $1.8 \mathrm{wt} \%(014)$ to $<0.1 \mathrm{wt} \%$ (019). At site 019 , the second assemblage $(57 \%$ in the surface sample) consists of tests of Cibicides lobatulus (Walker and Jacob), whereas Melonis zaandami and species of Cassidulina occur in minor amounts $(<10 \%)$ (Fig. 3 ). In sediments from site 018 the total number of foraminiferal tests is less than $1 \%$ in the $63-500 \mu \mathrm{m}$ fraction. Therefore, the data from site 018 are statistically insignificant. Detailed studies on the distribution of Cibicides lobatulus (Williamson et al., 1984; Mackensen, 1987; Wagener, 1988) have shown that this benthic foraminifer is adapted to coarse substrates, and it thus indicates strong bottom currents.

The most dominant terrigenous component of the $125-500 \mu \mathrm{m}$ fraction is quartz, with an amount of $1.6 \%$ in the adjacent basin and $8.8 \%$ in the ridge area. Feldspar, mica and metamorphic rock fragments also occur $(2.4-5.3 \%)$. The $>500 \mu \mathrm{m}$ fraction shows only small amounts $(<1 \%)$ of terrigenous particles (J. Bischof, pers. commun.). The presence of gneiss and quartzite suggests that these sediment components are ice-rafted debris from continental bedrock sources, probably in Greenland.

The coarse fraction composition of all samples is characterized by relatively small variations in the particle assemblages (Table 1).

\section{Clay-fraction mineralogy}

The $<2 \mu \mathrm{m}$ fraction is summarized in Table 1 . $\mathrm{X}$-ray diffraction analyses show abundant plagioclase at all sites. Montmorillonite, illite, kaolinite, chlorite, quartz and pyroxene also occur. The semiquantitative mineralogy of the $<2 \mu \mathrm{m}$ fraction is not presented because of the high content of plagioclase in the samples. Plagioclase as a framework silicate strongly alters the reflected signals of the X-ray diffraction analyses.

Previous investigations on Icelandic sediments that originate from the erosion of volcanic rocks show plagioclase to be one of the major constituents (Roaldset, 1983). Such sediments, which are 
redeposited by density currents, may be the most likely source for the abundance of fine detritus in the basin samples of boxcore 014 .

Boulton et al. (1988) show that gravity flows and turbidity currents are important agents for long-distance sediment transport and channel erosion on the southern continental shelf of Iceland. Another major source, but possibly less important, may be marine weathering of ridge crest rocks (Siever and Kastner, 1967).

\section{Grain-size distribution}

The grain-size distribution in the ridge area reflects differential response to the morpho- and hydrodynamic characteristics of the ridge (Fig. 4). The grain sizes decrease with increasing distance from the ridge crest. At basin site 014 the sediments are much finer than the ridge crest sediments, as indicated by the sorting index $\mathrm{S}_{0}$ (Table 2). This grain-size distribution and the mineralogical characteristics of the clay fraction suggest a suspension input by density currents that originated from the northern coast of Iceland. The sediments on the ridge are poorly to very poorly sorted. This seems to be a general trend, and is supported by grain-size investigations on Reykjanes Ridge by Horowitz (1974). Samples collected on the ridge consist of coarser sand, which is a reflection of large amounts of autochthonous volcanic detritus. With the exception of site 016 the cores show few vertical grain-size variations. The distribution fluctuations and the high sorting index $S_{0}$ at site 016 are probably caused by sediment transport down the slope. Settling velocity experiments show a bimodal grain-size distribution in the surface

\section{TABLE 2}

Median $(M d)$, quartile $\left(Q_{1}=\right.$ percentile $25, Q_{3}=$ percentile 75$)$ and sorting index $\left(S_{0}\right)$ from surface samples of sites 014 to 019. $M d, Q_{1}$ and $Q_{3}$ in millimetres

\begin{tabular}{llllll}
\hline & 014 & 015 & 016 & 019 & 018 \\
\hline$M d$ & 0.0016 & 0.42 & 0.1 & 0.3 & 0.16 \\
$Q_{1}$ & 0.0013 & 0.26 & 0.006 & 0.22 & 0.1 \\
$Q_{3}$ & 0.0018 & 0.78 & 0.23 & 0.45 & 0.2 \\
$S_{0}$ & 0.91 & 1.73 & 6.2 & 1.43 & 1.41 \\
\hline
\end{tabular}

sediments of site 016 , supporting the idea of redeposition (Oehmig and Wallrabe-Adams, in prep.).

The origin of the high amounts $(40-60 \%)$ of coarse sand at site 015 may be breakage or abrasion from the numerous exposed outcrops on the mid-ocean ridge. The samples collected from the ridge crest (sites 018 and 019 ) at about the 100-300 $\mathrm{m}$ water depth show an asymmetric grain-size distribution, with $60 \%$ in the $250-500 \mu \mathrm{m}$ and $125-250 \mu \mathrm{m}$ fractions of cores 019 and 018 respectively.

\section{Chemical composition of volcanic glass}

Due to the shallow-water environment of the volcanic activity, several morphological glass types occur, including subaerial and shallow-marine pyroclastites (e.g., highly vesiculated pumice-like particles). The glasses are predominantly of normal MORB composition. Only one type (colourless bubble walls and bubble junction shards) shows a more acid composition, with higher amounts of $\mathrm{Al}_{2} \mathrm{O}_{3}$ and $\mathrm{Na}_{2} \mathrm{O}$ and lower amounts of $\mathrm{Fe}_{2} \mathrm{O}_{3}$, $\mathrm{MgO}, \mathrm{CaO}$, and $\mathrm{TiO}_{2}$. These particles probably originated from a subaerial eruption on Iceland.

The average main element composition of the basaltic glasses is given in Table 3. For comparison, the composition of basaltic rocks and glasses from Kolbeinsey Ridge and the Mid-Atlantic Ridge are also shown. The element distribution of the Kolbeinsey glasses is nearly identical to that of other Mid-Atlantic Ridge glasses. Lower contents of $\mathrm{Na}_{2} \mathrm{O}$ and $\mathrm{K}_{2} \mathrm{O}$ and a slightly higher Fe content can be noted however.

\section{Bulk chemistry}

The chemical analysis for fifteen elements are presented in Table 4. Major elements are reported as oxides in weight percent, trace elements in parts per million.

Bulk carbonate contents were determined for all samples. Generally, the sediment is poor in carbonate, showing a decrease from $4.5 \mathrm{wt} \%$ on the plain $(014)$ to $<1 \mathrm{wt} \%$ in the ridge area. This reflects the predominant volcanic input in the ridge area and the slowly increasing pelagic biogenic input towards the adjacent plain.

Plots of the distribution of major and trace elements in the surface samples are shown in Fig. 5, 

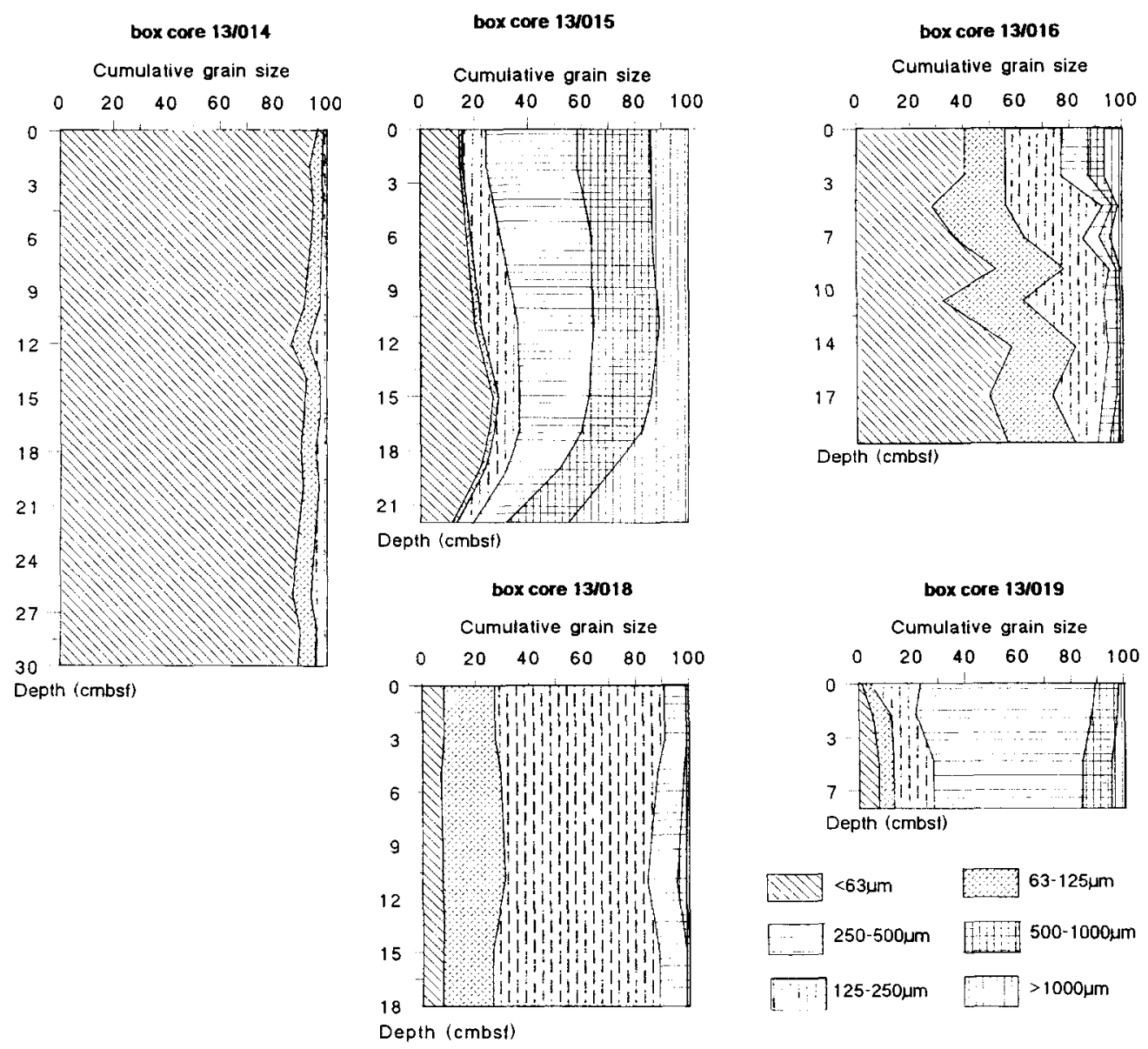

Fig. 4. Cumulative grain-size distributions at sites 014 to 019.

and they all reflect significantly different concentrations across the ridge compared with the basin. The metal distribution emphasizes the varying sedimentary sources that was indicated by the clayfraction mineralogy (see above).

Compared with non-ridge sediments $(014)$ the $\mathrm{CaO}, \mathrm{MgO}, \mathrm{Al}_{2} \mathrm{O}_{3}, \mathrm{Cr}, \mathrm{Cu}, \mathrm{Ni}$ and $\mathrm{Co}$ distributions display higher concentrations in the ridge sediments (015-019), and the elements are strongly correlated with each other. The presence of $\mathrm{Al}$ is attributed to terrigenous material, alteration of basalt, volcanic glass and hydrothermal exhalations (McMurtry and Yeh, 1981; Marchig et al., 1986). The coarse fraction analysis shows that most of the particles comprise volcanic glass that has been weathered to various degrees. The $\mathrm{Al}$ content of the ridge sediments occurs in amounts that are similar to those in the basaltic glass
(Table 3). Thus, it can be concluded that the $\mathrm{Al}$ content is positively correlated with volcanic input. $\mathrm{Fe}_{2} \mathrm{O}_{3}, \mathrm{CaO}$, and $\mathrm{MgO}$ show trends from the plain (014) to the ridge (015-019) that are similar to those for $\mathrm{Al}_{2} \mathrm{O}_{3}$ (Fig. 5). These trends correspond to the element pattern of the volcanic glass. The distribution pattern of $\mathrm{Fe}$ in the ridge sediment seems to be influenced by hydrothermal activity, which is shown by higher $\mathrm{Fe}$ vs. lower $\mathrm{Ca}-\mathrm{Mg}$ contents at site 016 (Fig. 5).

Concentrations of $\mathrm{Cr}, \mathrm{Cu}, \mathrm{Ni}$ and $\mathrm{Co}$ are also highest in the ridge samples. Because the volcanic glass predominates in the ridge sediments and the values of these trace elements (Table 4) are in good agreement with the metal composition of the basaltic rocks from the Kolbeinsey Ridge (Table 3), the concentrations of these trace elements may be related to the volcanic material. 


\section{TABLE 3}

Chemical composition of basaltic glass of the Kolbeinsey Ridge from this paper (nine analyses) and average compositions of basaltic rocks from the Kolbeinsey Ridge (calculated from Schilling et al., 1983, table 1 and 2, 28 analyses) and basalts and basaltic glasses from the Mid-Atlantic Ridge (Basaltic Volcanism Study Project, 1981). ${ }^{*}=$ total $\mathrm{Fe}$ as FeO. Oxides in wt \%; trace elements in ppm; n.d. $=$ no data; $S D=$ standard deviation

\begin{tabular}{|c|c|c|c|c|c|c|}
\hline & \multicolumn{2}{|c|}{$\begin{array}{l}\text { Kolbeinsey } \\
\text { basaltic glass } \\
\text { (this paper) }^{1}\end{array}$} & \multicolumn{2}{|c|}{$\begin{array}{l}\text { Average basaltic } \\
\text { rocks, Kolbeinsey } \\
\text { Ridge } \\
\text { (Schilling et al., } \\
\text { 1983) }\end{array}$} & \multirow[t]{2}{*}{$\begin{array}{l}\text { Average } \\
\text { Mid-Atlantic } \\
\text { Ridge basalt } \\
\text { (BVSP, 1981) }\end{array}$} & \multirow[t]{2}{*}{$\begin{array}{l}\text { Average basaltic } \\
\text { glass from } \\
\text { Mid-Atlantic Ridge } \\
\text { (BVSP, 1981) }\end{array}$} \\
\hline & & $S D$ & & $S D$ & & \\
\hline $\mathrm{SiO}_{2}$ & 50.61 & 1.10 & 50.13 & 1.05 & 49.21 & 50.68 \\
\hline $\mathrm{Al}_{2} \mathrm{O}_{3}$ & 13.32 & 1.37 & 14.50 & 0.77 & 15.81 & 15.60 \\
\hline $\mathrm{Fe}_{2} \mathrm{O}_{3}$ & & & 1.99 & & & \\
\hline $\mathrm{FeO}$ & $11.72^{*}$ & 1.31 & 9.42 & $1.73^{*}$ & $9.18^{*}$ & $9.85^{*}$ \\
\hline $\mathrm{MnO}$ & 0.20 & 0.02 & 0.20 & 0.02 & 0.16 & - \\
\hline $\mathrm{MgO}$ & 7.60 & 0.93 & 8.16 & 1.63 & 8.53 & 7.69 \\
\hline $\mathrm{CaO}$ & 11.71 & 1.22 & 12.18 & 1.32 & 11.14 & 11.44 \\
\hline $\mathrm{Na}_{2} \mathrm{O}$ & 1.72 & 0.32 & 2.02 & 0.27 & 2.71 & 2.66 \\
\hline $\mathrm{K}_{2} \mathrm{O}$ & 0.07 & 0.02 & 0.13 & 0.18 & 0.26 & 0.17 \\
\hline $\mathrm{TiO}_{2}$ & 1.19 & 0.24 & 1.07 & 0.27 & 1.39 & 1.49 \\
\hline $\mathrm{P}_{2} \mathrm{O}_{5}$ & n.d. & & 0.11 & 0.08 & 0.15 & 0.12 \\
\hline $\mathrm{Cr}_{2} \mathrm{O}_{3}$ & 0.02 & 0.02 & n.d. & & n.d. & n.d. \\
\hline $\mathrm{V}$ & n.d. & & 331 & 67.6 & n.d. & n.d. \\
\hline Co & n.d. & & 51 & 6.2 & n.d. & n.d. \\
\hline $\mathrm{Cr}$ & n.d. & & 250 & 153.5 & n.d. & n.d. \\
\hline $\mathrm{Ni}$ & n.d. & & 90 & 81 & n.d. & n.d. \\
\hline
\end{tabular}

\section{TABLE 4}

Element concentration of bulk sediment. Qxides in wt $\%$; trace elements in ppm; $S D=$ standard deviation; n.d. $=$ no detection; $R C \%=$ percent uncertainty at $1 \sigma ; L L D=$ lower limit of detection (ppm)

\begin{tabular}{|c|c|c|c|c|c|c|c|c|}
\hline & 014 & 015 & 016 & 019 & 018 & $S D$ & $R C \%$ & $L L D$ \\
\hline $\mathrm{Al}_{2} \mathrm{O}_{3}$ & 10.73 & 12.37 & 12.36 & 12.97 & 12.06 & 0.182 & 1.5 & 52 \\
\hline $\mathrm{Fe}_{2} \mathrm{O}_{3}$ & 11.19 & 12.81 & 12.84 & 11.39 & 12.66 & 0.278 & 3.7 & 28 \\
\hline $\mathrm{CaO}$ & 6.38 & 10.89 & 9.46 & $12.3 \mathrm{I}$ & 10.06 & 0.171 & 3.8 & 8 \\
\hline $\mathrm{MgO}$ & 5.45 & 9.76 & 8.80 & 10.63 & 9.40 & 0.167 & 2.0 & 121 \\
\hline $\mathrm{TiO}_{2}$ & 0.73 & 0.36 & 0.53 & 0.31 & 0.41 & 0.022 & 2.5 & 17 \\
\hline $\mathrm{K}_{2} \mathrm{O}$ & 1.14 & 0.30 & 0.74 & 0.19 & 0.57 & 0.027 & 1.0 & 34 \\
\hline $\mathrm{Ba}$ & 233 & 62 & 79 & 27 & 87 & 21 & 4.0 & 30 \\
\hline $\mathrm{Sr}$ & 284 & 104 & 146 & 84 & 100 & 8 & 2.4 & 2 \\
\hline $\mathrm{Cu}$ & 64 & 92 & 85 & 97 & 71 & 10 & 5.0 & 5 \\
\hline $\mathrm{Ni}$ & 40 & 55 & 52 & 82 & 60 & 11 & 3.0 & 5 \\
\hline $\mathrm{Co}$ & 25 & 45 & 43 & 52 & 43 & 5 & 9.3 & 8 \\
\hline $\mathrm{Cr}$ & 35 & 75 & 80 & 218 & 141 & 20 & 3.0 & 5 \\
\hline $\mathrm{Zr}$ & 165 & 55 & 86 & 31 & 77 & 10 & 4.5 & 2 \\
\hline $\mathrm{Pb}$ & 24 & 5 & 7 & 6 & 8 & 6 & 11.8 & 4 \\
\hline $\mathrm{Nb}$ & 15 & 3 & 5 & n.d. & 6 & 4 & 4.6 & 2 \\
\hline
\end{tabular}



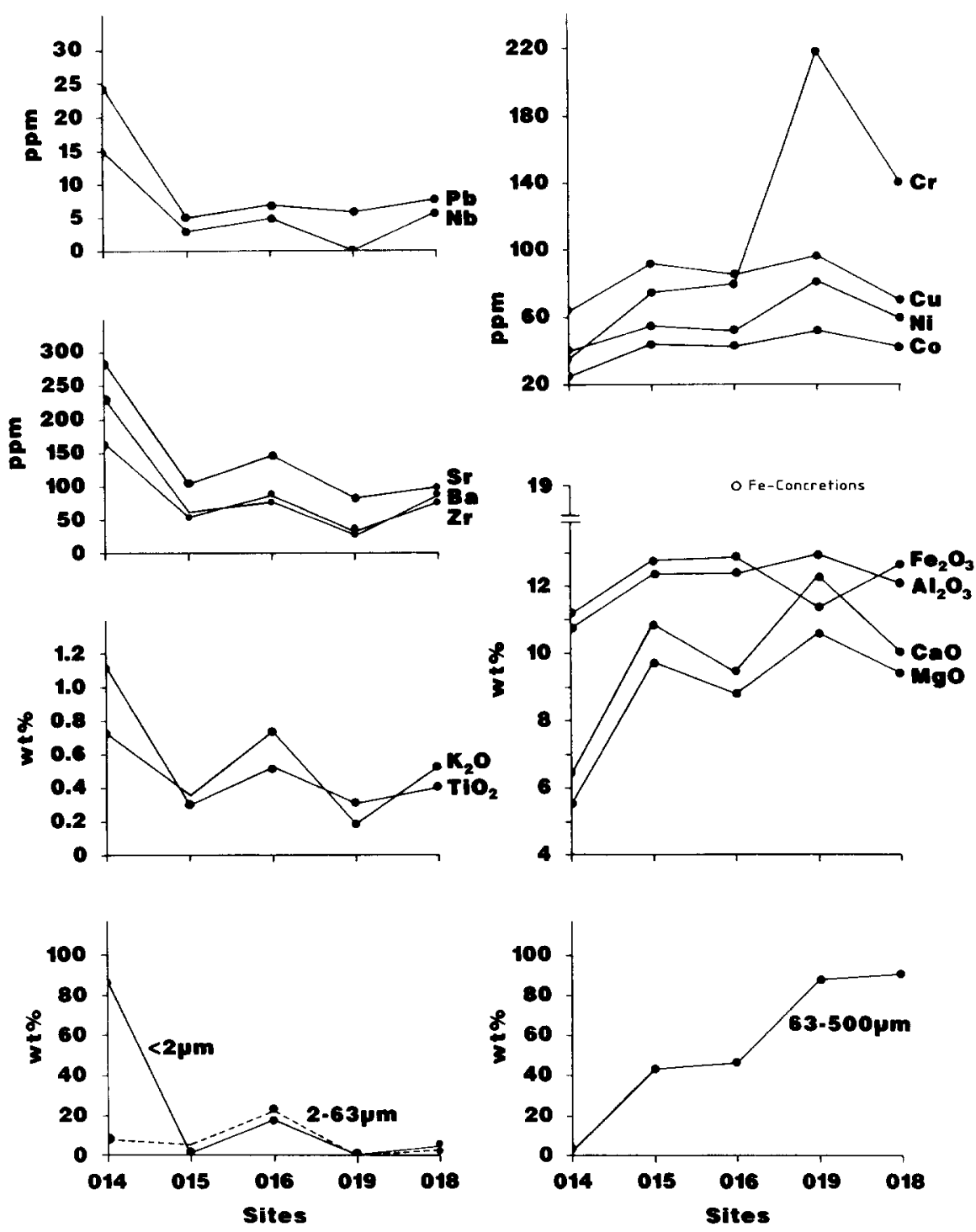

Fig. 5. Element concentration trends compared to the content of $<2 \mu \mathrm{m}, 2-63 \mu \mathrm{m}$ and $63-500 \mu \mathrm{m}$ fractions in the surface sediments of sites 014 to 019 . The $\mathrm{Fe}_{2} \mathrm{O}_{3}$ content of concretions at site 016 is also shown.

$\mathrm{Ba}$ and $\mathrm{Sr}$ concentrations range from $240 \mathrm{ppm}$ and $280 \mathrm{ppm}$ on the plain to $90 \mathrm{ppm}$ and $100 \mathrm{ppm}$ on the ridge crest and may be the result of dissolution of biogenic calcareous components (Goldberg and Arrhenius, 1958; Heath and Dymond, 1977; Lea and Boyle, 1989). SEM investigations show that foraminifer tests from surface sediments of site 014 exhibit strong corrosion due to dissolution. $\mathrm{Pb}$ and $\mathrm{Nb}$ reveal higher values with increasing distance from the ridge crest, with the highest values at site 014 .

\section{Discussion}

\section{Indications of hydrodynamic processes}

The results of the grain-size analyses reveal various grain-size distributions, which indicates a variety of hydrodynamic processes. Samples collected on the ridge crest (site 018 and 019) consist of high amounts of fine to medium sand (Fig. 4 and Table 1). The low content of clay and silt in addition to the good sorting index at site 019 
indicates that the fine fraction has been winnowed out by currents. The strong association found between the sand fraction and the benthic species C. lobatulus which is adapted to high bottom currents indicates a higher velocity of bottomwater currents over this part of the ridge crest. This association between coarse grain sizes, $C$. lobatulus and a high-energy environment has also been reported by other authors (Mackensen, 1987; Wagener, 1988). The East Iceland Current, which circulates in the area between Iceland and Jan Mayen (Fig. 1) and reaches down to a water depth of several hundred metres, with gradually decreasing velocities (Stefansson, 1962), is presumed to be the reason for these erosional processes, the ridge crest lying partly above the $200 \mathrm{~m}$ water depth.

The slope sediments are affected by reworking and redistribution processes (downslope mass transfer), as suggested by strong fluctuations in grain size and multimodal settling velocities (Oehmig and Wallrabe-Adams, in prep.). Deposition of ridge-derived material on the flanks has produced volcaniclastic aprons.

The peri-basin sediments were sampled at site 014 . At this site the finest sizes $(<125 \mu \mathrm{m})$ play the dominant role, possibly reflecting a low-energy zone. However, Liu and Zarillo (1989) have described fine grain sizes in a very high energy environment off the south shore of Long Island. These authors interpret this association to be the result of excess input of these grain sizes into this high-energy zone as the result of bluff erosion. There was no indication of any relationship between dynamic equilibrium processes and energetic processes; the influence of an external source of sediment was instead being reflected.

Similarly, for site 014 we assume suspension decantation due to density currents coming from Iceland, leading to an excess input of fine grain sizes (e.g., plagioclase, montmorillonite and fine volcanic detritus). This hypothesis is supported by the dominance of plagioclase in the clay fraction.

The accumulation of fine material is accompanied by resuspension of organic matter possibly derived from Iceland. Rapid burial of reworked terrigenous organic matter would contribute to a relatively stable organic phase that causes the elevated organic carbon contents of the basin sediments.

The depositional reconstructions illustrate the changes in the distribution of sediment facies between ridge and adjacent basin, and basinwide dispersal of the ridge-derived volcaniclastics is not possible.

Coherence between grain size and major and minor element distribution

Significant differences in grain-size distribution curves imply that the element concentrations are inhomogeneously distributed. Within the grainsize spectrum, the finer grained fraction-consisting mainly of clay minerals - shows relatively high metal contents. Salomons and Förster (1984) suggest that the $<63 \mu \mathrm{m}$ and $>63 \mu \mathrm{m}$ fractions are useful for the interpretation of geochemical results, and in this regard grain-size distribution curves are compared with the concentration profiles of the studied elements in Fig. $5\left(\mathrm{Al}_{2} \mathrm{O}_{3}\right.$, $\mathrm{Fe}_{2} \mathrm{O}_{3}, \mathrm{MgO}, \mathrm{CaO}, \mathrm{TiO}_{2}, \mathrm{~K}_{2} \mathrm{O}, \mathrm{Ba}, \mathrm{Sr}, \mathrm{Zr}, \mathrm{Co}$, $\mathrm{Cr}, \mathrm{Ni}, \mathrm{Cu}, \mathrm{Nb}$ and $\mathrm{Pb}$ ).

From the ridge crest to the adjacent plain the clay fraction $(<2 \mu \mathrm{m})$ increases up to $>80 \mathrm{wt} \%$, and this has a strong effect on the distribution of some of the major and minor elements: when the $<2 \mu \mathrm{m}$ fraction increases the concentrations of $\mathrm{TiO}_{2}, \mathrm{~K}_{2} \mathrm{O}, \mathrm{Ba}, \mathrm{Sr}, \mathrm{Zr}, \mathrm{Nb}$ and $\mathrm{Pb}$ also increase. The element concentrations at sites 015-019 do not differ significantly however. The general trend in these elements follows the $<2 \mu \mathrm{m}$ grain-size curve, supporting the close relationship between element concentration and grain-size distribution in the ridge area. In particular, the significant trend from site 014 to the ridge sites 015-019 suggests that these elements are associated with very fine grain sizes. The fine fraction consists mainly of plagioclase and montmorillonite, which may be responsible for the enhanced content of $\mathrm{TiO}_{2}$ (Lange, 1974).

$\mathrm{Ba}$ and $\mathrm{Sr}$ concentrations are often interpreted as dissolution residues (Goldberg and Arrhenius, 1958; Heath and Dymond, 1977). The enrichment of $\mathrm{Ba}$ and $\mathrm{Sr}$ with increasing distance from the ridge crest corresponds to an increasing $\mathrm{CaCO}_{3}$ content. 
The $\mathrm{CaO}, \mathrm{MgO}, \mathrm{Al}_{2} \mathrm{O}_{3}, \mathrm{Cr}, \mathrm{Cu}, \mathrm{Ni}$ and $\mathrm{Co}$ curves are strongly correlated with the $63-500 \mu \mathrm{m}$ fraction curve. The $63-500 \mu \mathrm{m}$ fraction is predominantly composed of volcanic glass, which shows a chemical composition that is similar to that of this fraction (Table 3).

The highest $\mathrm{Fe}$ concentrations, which are partly to be found in Fe-rich concretions, occur at site $016(19.3 \mathrm{wt} \%)$ and correspond to lower $\mathrm{CaO}$ and $\mathrm{MgO}$ concentrations. This suggests that the $\mathrm{Fe}$ content in these sediments is the result of a mixture of volcanic glass and hydrothermal input. The concentration profile of $\mathrm{Fe}$ may therefore not be in good agreement with the other elements, thus providing an example of the fact that grain size is not the only factor influencing the distribution of metals in this area.

Generally, however, the concentration profiles for most of the elements in the surface samples can be explained in terms of grain-size distribution and the associated particle composition.

The bulk chemical patterns indicate that the Kolbeinsey Ridge is an important source for most of the $\mathrm{Fe}, \mathrm{Al}, \mathrm{Mg}, \mathrm{Cr}, \mathrm{Cu}, \mathrm{Ni}$ and $\mathrm{Co}$ at sites 015-019. The higher correlation between the fine grain sizes and $\mathrm{TiO}_{2}, \mathrm{~K}_{2} \mathrm{O}, \mathrm{Zr}, \mathrm{Nb}$ and $\mathrm{Pb}$ seems to be due to transported alteration products of basalts from Iceland.

\section{Conclusions}

(1) Large quantities of fine-grained sediment in the basin have been transported by density currents from Iceland. Dispersed volcanic material, clay minerals and plagioclase derived as alteration products from rocks on Iceland are the major components in this basin facies.

(2) Coarse grain sizes and the benthic foraminifer Cibicides lobatulus indicate strong bottom currents along the ridge crest south of Kolbeinsey Island at a water depth of $100-300 \mathrm{~m}$. These bottom currents were probably caused by the East Iceland Current and the ridge topography.

(3) $\mathrm{Al}, \mathrm{Fe}, \mathrm{Mg}$ and the trace elements $\mathrm{Cr}, \mathrm{Cu}$, $\mathrm{Ni}$ and $\mathrm{Co}$ are associated with ridge-derived volcanic material. This appears to be typical on active ridges. High amounts of $\mathrm{Ti}, \mathrm{K}, \mathrm{Zr}, \mathrm{Nb}$ and $\mathrm{Pb}$ are associated with the very fine grain sizes $(<2 \mu \mathrm{m})$ and are probably the result of alteration products from Iceland.

(4) $\mathrm{Ba}$ and $\mathrm{Sr}$ concentrations in the adjacent basin are associated with the higher calcium carbonate content and are probably caused by carbonate dissolution.

In summary, the spatial pattern of sediment fluxes and the changes in the geochemical composition can be attributed to two important sediment sources in the area north of Iceland-subaqueous eruptions at the mid-ocean ridge spreading centre and resuspended fine material from Iceland.

\section{Acknowledgements}

We thank $\mathbf{J}$. Thiede for supervising the project, our colleagues W. Brückmann, R. Oehmig and D. Nürnberg for discussion and S. Baade, A. Kohly, S. Körsgen and S. Rumohr for sample preparation and technical assistance. We also thank Capt. Greve and his crew of the R.V. Polarstern and Prof. M. Spindler (Alfred Wegener Institute), the Chief Scientist on cruise ARK V/1.

This investigation forms part of the research project "The Greenland-Scotland-Ridge" and was funded by the Bundesministerium für Forschung und Technologie.

\section{References}

Basaltic Volcanism Study Project (BVSP), 1981. Basaltic Volcanism on the Terrestrial Planets. Pergamon, New York, 1286 pp.

Boulton, G.S., Thors, K. and Jarvis, J., 1988. Dispersal of glacially derived sediment over part of the continental shelf of South Iceland and the geometry of resultant sediment bodies. Mar. Geol., 83: 193-223.

Goldberg, E.D. and Arrhenius, G., 1958. Chemistry of pelagic sediments. Geochim. Cosmochim. Acta, 13: 153-212.

Heath, G.R. and Dymond, J.R., 1977. Genesis and diagenesis of metalliferous sediments from the East Pacific Rise, Bauer Deep, and Central Basin, northwest Nazca plate. Geol. Soc. Am. Bull., 88: 723-733.

Horowitz, A., 1974. The geochemistry of sediments from the northern Reykjanes Ridge and the Iceland-Faroes Ridge. Mar. Geol., 17: 103-122.

Lange, J., 1974. Geochemische Untersuchungen an pelagischen Sedimenten des atlantischen und pazifischen Ozean (DSDP. Leg I- VII). Ph.D. Thesis, Univ. Göttingen.

Lea, D. and Boyle, E., 1989. Barium content of benthic foraminifera controlled by bottom-water composition. Nature, 338: 751-753. 
Liu, J.T. and Zarillo, G.A., 1989. Distribution of grain sizes across a transgressive shoreface. Mar. Geol., 87: 121-136.

Mackensen, A., 1987. Benthische Foraminiferen auf dem Island-Schottland Rücken: Umwelt-Anzeiger an der Grenze zweier ozean ischer Räume. Paläontol. Z., 61: 149-179.

Marchig, V., Erzinger, J. and Heinze, P.-H., 1986. Sediment in the black smoker area of the East Pacific Rise $\left(18.5^{\circ} \mathrm{S}\right)$. Earth Planet. Sci. Lett., 79: 93-106.

McMurtry, G.M. and Yeh, H.-W., 1981. Hydrothermal clay mineral formation of East Pacific Rise and Bauer Basin sediments. Chem. Geol., 32: 189-205.

Oehmig, R. and Wallrabe-Adams, H.-J., in prep. Hydrodynamic properties of volcanic particles and sedimentologic conditions at the southern Kolbeinsey Ridge crest and slope. J. Sediment Petrol.

Roaldset, E., 1983. Tertiary (Miocene-Pliocene) interbasalt Sediments, NW and W Iceland. Jökull, 33: 39-56.

Salomons, W. and Förstner, U., 1984. Metals in the Hydrocycle. Springer, Berlin, $332 \mathrm{pp}$.

Schilling, J-G., Zajac, M., Evans, E., Johnston, T., White, W.,
Devine, J.D. and Kingsley, R., 1983. Petrologic and geochemical variations along the Mid-Atlantic Ridge from $29^{\circ} \mathrm{N}$ to $73^{\circ}$ N. Am. J. Sci., 283: 510-586.

Siever, R. and Kastner, M., 1967. Mineralogy and petrology of some Mid-Atlantic Ridge sediments. J. Mar. Res., 25: 263-278.

Spindler, M. (Editor), 1989. The Expeditions ARKTIS V/la, $\mathrm{lb}$ and 2 of RV "Polarstern" 1988. Rep. Polar Res., 59.

Stefansson, U., 1962. North Icelandic Waters. Rit Fikideildur, Reykjavik, Vol. III, 269 pp.

Vogt, P.R., 1983. The Iceland mantle plume: Status of the hypothesis after a decade of new work. In: M.H.P. Bott, S Saxov, M. Talwani and J. Thiede (Editors), Structure and Development of the Greenland-Scotland Ridge. (NATO Conference Ser. IV, Vol 8.) Plenum, New York, pp. 191-213 Wagener, M., 1988. Quartäre und rezente benthische Foraminiferen der Island-Färöer-Schwelle. Facies, 19: 97-128.

Williamson, M.A., Keen, C.E. and Mudie, P.J., 1984. Foraminiferal distribution on the continental margin off Nova Scotia. Mar. Micropaleontol., 9: 219-239. 